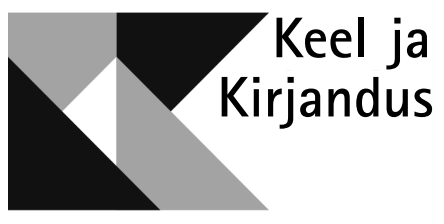

\title{
NULLTULETUS JA KONVERSIOON EESTI KEELES
}

REET KASIK

\section{Sõnaliigivahetusest teoreetiliselt}

$\mathrm{P}$ aljudes keeltes, kaasa arvatud eesti keeles, on tuttav protsess, millega leksikaalsed üksused muudavad oma sõnaliigilist kategooriat ilma sõnatüve vormiliste muutusteta. Kõige üldisemalt tuntakse seda nähtust konversiooni nime all. Konversiooni olemusest ja kohast keelekirjelduses on lingvistilises kirjanduses diskuteeritud alates 1960. aastatest, ülevaate konversiooni käsitluse ajaloost kuni 1990. aastateni on esitanud Jan Don (1993), hilisematest uurimustest Rochelle Lieber (2005). Põhilised teoreetilised seisukohad on järgmised.

1. Konversioon on derivatsiooniga võrreldav sõnamoodustuse osa, mida nimetatakse nulltuletuseks. Konversioon kujutab endast fonoloogilise nullafiksi lisandumist sõnatüvele ja konversiooni tulemus on paralleelne afiksilise moodustuse tulemusega, s.t tähendusseose põhjal on eristatav alussõna ja sellest moodustatud tuletis.

2. Konversioon on morfosüntaktiline protsess, afiksita kategooriamuutus, kus sõnaliik vaheldub tekstis ilma struktuurimuutuseta.

3. Konversioon on sõnaloome nagu uudis- või tehissõna loomine. See pole suunaga protsess nagu derivatsioon, vaid pigem ümberpaigutamise või ümberkategoriseerimise protsess leksikonis. Kui noomenist tuleb verb, sisestatakse see lihtsalt mentaalsesse leksikoni uue lekseemina. 
Nii struktuuri- (Marchand 1969) kui ka protsessimorfoloogias (Don 1993; Beard 1995) käsitatakse konversiooni leksikaalse derivatsiooniga võrreldava suunatud protsessina, kus üks leksikoniüksus on teisest motiveeritud. Osa nulltuletuse olemasolu aktsepteerivatest lingvistidest näeb konversiooni laiema nähtusena kui nulltuletus (Pennanen 1971). Selliselt tutvustab konversiooni oma sõnamoodustuse mõisteid käsitlevas ülevaates ka Krista Kerge (1990: 20-21). Konversiooni kui sõnaloome eri aspekte on analüüsinud nt Eve ja Herbert Clark (1979), Pavol Štekauer (1996), Ingo Plag (1999), Rochelle Lieber (2004). Selline konversioonianalüüs pole ei struktuuri- ega protsessipõhine. Põhiliseks väitlusobjektiks on semantika - osa lingviste (näiteks Štekauer 2006) kirjeldab konversiooni semantilisi võimalusi kui derivatsiooniprotsessidega võrreldavaid, teised leksikaalse konversiooni uurijad on osutanud, et konversiooni teel saadud sõnade tähendused ei ole fikseeritud, vaid põhinevad suhtluskokkulepetel, on tõlgendatavad kontekstipõhiselt ega ole piiratud afiksilise sõnatuletuse võimalustega. Nii väidab inglise neologisme analüüsinud Rochelle Lieber, et uute konversiooniverbide semantiline väli inglise keeles katab nii tuletatud kui ka tuletamata verbide semantilise välja (Lieber 2004). Kogu see teoreetiline diskussioon on käinud põhiliselt inglise keele baasil, viidetega ka teistele analüütilistele keeltele. Seetõttu on kanooniline vaatepunkt konversioonile lähtunud eeskätt homonüümse konversiooni problemaatikast, keskendudes fonoloogilisele tõlgendamisele, semantikale ja süntaksile.

Muutemorfoloogiaga keeltes on probleemid osalt teistsugused (konversioonitüüpide mitmekesisuse kohta maailma keeltes vt Stekauer jt 2012: 213-224). Kuigi sõnaliigivahetus toimub ilma tuletusliiteta, võib konversiooniga kaasneda muid vormimuutusi. Eesti keeles on näiteks homonüümse konversiooni kõrval (substantiivide ja adjektiivide liigivahetus) tavapärane konversiooniga kaasnev morfoloogilise paradigma muutus (noomeni ja verbi erinev muuteparadigma), sõnatüve asemel sõnavormi konverteerumine teiseks sõnaliigiks (partitsiipide adjektiivistumine, käändevormide adverbistumine), sõnaliigimuutusega kaasnevad tüve häälikumuutused ehk erinevad tüvevariandid (eesti keeles nt astmevaheldus ja lõpukadu, vrd lubama:lubab ja luba : loa; uskuma : usub ja usk : usu). Kuna eesti keeles on ka ühest vokaalist koosnevaid tuletusliiteid $(-u,-i,-e)$, moodustab omaette probleemi vokaalliite ja mitteliitelise tüvevokaali eristamine.

Eesti lingvistidest on konversiooni põhjalikumalt käsitlenud Henn Saari (1993) ja Silvi Vare (1993, 2004, 2005), kumbki eri lähtealustelt, aga omavahelisest diskussioonist hoidudes. Saari käsitlus on eeskätt vormiteoreetiline, eesti näitematerjal on tal rohkem oma mõttekäikude illustratsiooniks. Ta arutleb mõistemahtude ja mõistepiiride ning nende tähistamiseks kasutatavate terminite ambivalentsuse üle. Oluliseks tuleb pidada Saari osutust, et eesti (või avaramalt läänemeresoome) grammatiline süsteem ei haaku probleemideta analüütiliste keelte lingvistilistel süsteemidel põhinevate tõlgendustega. Saari nimetab oma uurimisvaldkonda sõnagrammatikaks ja keskendub sõnade fonoloogilisele ja morfoloogilisele struktuurile. Konversiooni mõiste mitmetähenduslikkuse tõttu ei pea ta mõistlikuks seda terminit eesti keele puhul kasutada. Tema termin on liigivaheldus ja ta jõuab järeldusele, et sõnaliigivaheldus ei ole läänemeresoome eeldustel enamasti moodustus ja järelikult ka mitte sõnamoodustus, mistõttu ei pea ta võimalikuks rääkida ka nullsufiksist. Saari on oma artikliga üritanud tõmmata piiri moodustuse ja 
mittemoodustuse vahele. Ta keskendub vormile, pidades seda kindlamaks pidemeks kui sisu, kuid tunnistab, et tülikusele vaatamata ei pääse viimasest mööda.

Silvi Vare küll viitab konversiooni mõiste ambivalentsusele, aga ei arutle põhjalikumalt konversiooniga seotud teoreetiliste probleemide üle. Ühelt poolt peab ta nulltuletust ja otsetuletust konversiooni rööpnimetusteks (Vare 2004: 915-916, 2005: 39). Samal ajal ei vaatle ta analüüsitavate sõnade morfoloogilist struktuuri ega vastanda liitega ja liiteta tuletisi, vaid mõistab konversiooni minu arusaamist mööda eeskätt leksikaalselt, pidades konversiooniks nii juursõnade, tuletiste kui ka liitsõnade üleminekut ühest sõnaliigist teise (Vare 2005: 39). Konversiooni olemuse kohta tõdeb ta sellegipoolest, et konversioon on üks sõnamoodustusviise nagu tuletuski ja et ka konversiooni sünkroonilise käsitluse korral saab rääkida moodustussuunast (Vare 2005: 41). Nii kirjeldab ta ühes artiklis deverbaalseid noomeneid (Vare 2004), teises denominaalseid verbe (Vare 2005). Konversioonisuhte olemasolu kriteeriumiks ja moodustussuunaks peab ta konversioonipaari ühe liikme seletamist teise kaudu ÕS-i ja EKSS-i sõnaseletustes (Vare 2005: 44). Ta viitab küll konversiooni ja liitelise sõnatuletuse põhimõtteliselt sarnasele funktsioonile keeles (Vare 1993: 45-46), aga ei analüüsi konversioonipaari liikmete tähendusvahekordi ega võimalikku paralleelsust sufiksilises sõnatuletuses väljenduvate regulaarsete derivatiivsete tähendustega, kirjeldades üksnes noomeni ja verbina esinevate sõnatüvede fonoloogilist struktuuri.

Erinevalt Saarist, kes vaatleb samadelt alustelt kõiki eesti keeles võimalikke sõnaliigivaheldusi, eristab Vare konversioonist kui sõnamoodustusviisist nn puhtsüntaktilise konversiooni ehk transpositsiooni. Esimesel juhul tekib Vare järgi uus leksikoniüksus, teisel juhul on tegemist kontekstuaalse liigivahetusega. Vare jaoks tähendab uus leksikoniüksus sõna esinemist sõnaraamatus (ÕS-is) eri märksõnana. Sellest lähtudes peab ta konversiooniks verbi ja noomeni liigivaheldust, mitte aga substantiivi ja adjektiivi liigivaheldust, sest sõnavaras (loe: ÕS-is $-R$. K.) ei ole kaht eri sõna, tark substantiivina ja tark adjektiivina (Vare 2004: 915-916). Tegelikult võib ka substantiivide ja adjektiivide vahel täheldada motivatsioonisuunda adjektiivist substantiiviks (haige, tark, pime, loll) või substantiivist adjektiiviks (sant, koer, maru, räbal), mille puhul üks kasutus on primaarne, teine sekundaarne.

Vaatlen siinses artiklis sarnaselt Silvi Vare ja enamiku konversiooniuurijatega konversiooni tuumosa - noomeni ja verbi liigivahetust -, aga eelistan argumendina eesti keele struktuurist lähtuvat põhjendust: samatüvelisel noomenil ja verbil on eesti keeles erinev muuteparadigma, mistõttu on kahtlusteta tegemist eri lekseemidega, sõltumata sellest, kas ja kuidas nad kuskil sõnaraamatus on esitatud. Seetõttu võib noomeni ja verbi liigivahetust käsitledes jätta kõrvale süntaktilised ja kontekstuaalsed argumendid ning keskenduda üksnes morfoloogilisele ja semantilisele analüüsile.

Silvi Vare konversioonikäsitluse põhiprobleem on selles, et ta lähtub inglise keele (või avaramalt indoeuroopa keelte) põhjal sõnastatud konversiooni määratlusest - sõnaliigiline kategooria muutub ilma sõnatüve vormiliste muutusteta -, aga eesti keeles on vormiliselt muutumatuid sõnatüvesid vähe. Kuidas kohandada konversiooni mõistega eesti keele grammatilisest süsteemist johtuvaid liht- ja komplekssete tüvede (kaasa arvatud tuletusliidete) mitmekesiseid variante ja lahendada lingvistiliste süsteemide erinevustest tulenevaid 
probleeme, mille üle Henn Saari oma põhjalikus artiklis (1993) arutleb, sellele ei ole Silvi Vare oma konversiooniartiklites minu meelest rahuldavat lahendust leidnud. Käsitlen seda teemavaldkonda järgnevas lähemalt.

\section{Nulltuletus või liiteline tuletus}

Käesoleva artikli eesmärk on näidata, et eesti samatüveliste verbide ja noomenite vahel on tuletusvahekord ja seda tuletustüüpi on loogiline nimetada nulltuletuseks. Seetõttu on mõistlik lähtuda tuletussüsteemi kirjeldamise põhimõtetest ja mõistetest. Lekseemi, millest tuletis on moodustatud, nimetatakse alussõnaks. Sufiksilise tuletuse puhul moodustab alussõna tüvi osa tuletise tüvest, s.t tuletis on kompleksse struktuuriga. Tuletustüvi on see osa alussõnast, mis jääb järele, kui liide eraldada. Nulltuletuse puhul on alussõna, tuletustüvi ja tuletis kõik samakujulised. Sõnaliigi määravad tüvele liituvad muutetunnused. Ühte juurtüve sisaldavad sõnad jagunevad morfoloogilise struktuuri alusel kolme rühma.

1. Kui muutetunnus(t)e ees on lihttüvi, millele liituvad vaid ühe sõnaliigi muutetunnused, siis ei ole tegemist sõnamoodustusega.

2. Kui muutetunnus(t)e ees on kompleksne tüvi, on tegemist sufiksilise tuletisega.

3. Kui muutetunnus(t)e ees on lihttüvi, millele võivad liituda nii noomeni kui ka verbi muutetunnused, on tegemist nulltuletusega

Eesti noomeni- ja verbitüved on sarnase fonoloogilise koostisega. Tüüpilised lihttüved on ühe- või kahesilbilised vokaaltüved (maa, sõna, roosa, too-ma, ela-ma, käski-ma). Ajaloolise kulumise tõttu on eesti keeles ka palju ühesilbilisi konsonantlõpulisi lihttüvesid (jalg, mets, muld, seis-ma, murd-ma, laul$m a$ ). Konsonantlõpulistel muutuvatel sõnadel (noomenitel ja verbidel) on alati ka vokaallõpuline tüvevariant (jalga, metsa, mulda, seisa-b, murra-b, laula-b). Siiski ei erine lihtsõnad ja tuletised sõnakuju poolest alati üksteisest. Ühesilbiliste konsonantlõpuliste ja kahesilbiliste vokaallõpuliste tüvede hulgas on ka tuletisi (käi-k, loe-nd, sad-u, tõug-e, kee-t-ma, võlg-ne-ma).

Sõnasisesed morfeemipiirid on mõnikord selged, teinekord ebaselged. Seetõttu võivad ka piirid sõna struktuuritüüpide vahel, eriti lihtsõnade ja tuletiste vahel, olla ähmased. Mingi hulk $u$ - ja $i$-tüvelisi verbe on ajaloolised, aga tänapäevaks tuhmunud tuletised, mille puhul võimalikku alussõna või samatüvelist korrelaatsõna ${ }^{1}$ tänapäeva keeles ei tunta ja mida seetõttu võib sünkrooniliselt tõlgendada lihttüvedena (uskuma, kõndima jt - vt ka Rätsep 2002). Ka ajalooliste $u$ - ja $i$-liiteliste noomenite hulgas on selliseid, millel ei ole tänapäeva keeles erineva tüvevokaaliga alussõna või korrelaatsõna ja mis seetõttu on tõlgendatavad lihttüvedena (sund, sünd, rööv; maht, usk, kulu). Kui sellised morfoloogiliselt liigendamatud sõnatüved on kasutusel nii noomenina kui ka verbina, võib nõustuda, et tänapäeva keele seisukohast on nende vahel konversioonisuhe.

1 Korrelaatideks on tuletuslikus mõttes sellised sõnad, millel ei ole lekseemina käibivat alussõna, aga on sama fonoloogilise kujuga tuletustüvi. Neid ei saa tõlgendada teineteise tuletistena, nagu näiteks mõtlema ja mõte, mäletama ja mälu, kahtlema ja kahtlane. Samatüvelistele korrelaatsõnadele toetudes võib ka sünkrooniliselt läbipaistmatus sõnas näha moodustusosi, nt tajuda sõnas mõte e-liidet (vrd mõtlema) või deskriptiivsõnas $k \ddot{a ̈ a ̈ k-~}$ suma u-liidet (vrd kääksatama, kääksti). 
Silvi Vare tõlgendab konversiooni nii avaralt, et koondab selle mõiste alla ka suure osa eesti keele traditsioonilisest ja läbipaistvast sufiksilisest sõnatuletusest. Vare on kogenud derivatsiooniuurija ja ma ei väida, et ta ükskõik missugust liidet ära ei tunne, kui see sõnas esineb. Ma diskuteerin konversiooni mõiste üle Vare käsitluses ega saa nõustuda sellega, et Vare ei tõmba konversiooni ja liitelise sõnatuletuse vahele selget piiri. Kuna ta lähtub üksnes fonoloogilisest sõnakujust, siis ei erista ta kompleksseid tüvesid lihttüvedest. Fonoloogiliselt samakujulisel liitel võib olla semantiliselt selgelt erinev funktsioon, mispuhul on tegemist kahe erineva liitega, mitte ühe polüseemilise liitega. Kui piirduda verbide ja noomenite vahekorraga, siis selgemaid selliseid juhtumeid on fonoloogiliselt identsed verbiliide $-i$ (sähv-i-ma) ja substantiiviliide $-i$ (uinut- $i$ ), verbiliide $-u$ (selg- $u-m a)$ ja substantiiviliide $-u$ (teg- $u$ ), verbiliide -ne (kalli-ne-ma) ja adjektiiviliide -ne (soola-ne). Kui need juhtuvad liituma samale tüvele, on Vare tõlgenduses tegemist konversiooniga, mitte kahe erineva liite abil moodustatud tuletistega. Vare artiklites küll adjektiivinäiteid ei ole, aga sellised paralleeltuletised on nt sarnane ja sarnanema, tusane ja tusanema, mõrane ja mõranema.

Konversiooni piire Vare mõistes avardab veelgi rohkem see, et ta võtab arvesse ainult liidete sarnaseid konsonante, elimineerib aga erinevad vokaalid. Nii on Vare jaoks põhimõtteliselt samad liited verbiliide - $n d a$ ja noomeniliide -ndi (Vare 1993: 40, 2005: 49), verbiliide -tse ja noomeniliide -tsa (Vare 2005: 50) ja nende tuletised on konversioonisuhtes. Sellise otsuseni jõuab Vare nii, et ei võta arvesse sõnatüve fonoloogilisi variante, vaid käsitab sõnana sõnaraamatu märksõnastikus esikohal olevat sõnakuju, nn algvormi. Noomenitel on see nominatiiv, verbidel $m a$-infinitiivi tunnuse ees olev tüvekuju. Kuna vokaalid „ei loe”, võibki ta tõdeda, et sõnaliik muutub ilma sõnatüve vormiliste muutusteta. Lähtumine sõnaraamatus antud sõnaseletustest ei ole minu meelest teaduslikult pädev argument. Nii on moodustussuunana fikseeritud $\mathrm{V}>\mathrm{S}$ laiendama > laiend, sest laiend on sõnaraamatu järgi 'laiendatud koht', aga $\mathrm{S}>\mathrm{V}$ pärand > pärandama, sest pärandama on sõnaraamatus seletatud 'pärandiks jätma' (Vare 2005: 49-50). Aga kui sõna pärand ei oleks sõnaraamatus seletatud kui 'pärijatele siirduv surnud isiku vara', vaid näiteks 'pärandatud vara', kas siis oleks moodustussuund olnud V $>\mathrm{S}$ ? $n d a$-liiteliste verbide ja $n d$-liiteliste substantiivide tuletusvahekorda olen käsitlenud mujal (Kasik 2011), sellepärast ma sellel siin pikemalt ei peatu. Sõnade kaabits > kaabitsema vahel tuvastab Vare konversioonisuhte, toetudes 1999. aasta ÕS-ile, sest seal on sõnaseletuseks kaabitsema 'kaabitsaga töötlema', teistes sõnaraamatutes, kus kaabitsema-verbi tähendust on seletatud 'vähehaaval kaapima', ei ole aga kaabitsa ja kaabitsema vahel konversioonisuhet, vaid kaabitsema on tse-liiteline tuletis verbist kaapima (Vare 2005: 50). Sõnaraamat sõnaraamatuks, aga kumb ta siis eesti keele sõnamoodustussüsteemis on: tse-tuletis või nulltuletis?

Vokaalliited on nii muutemallide kui ka oma üleüldise areduse poolest märksa probleemsemad kui konsonante sisaldavad liited. Kuna Vare absolutiseerib sõnana nominatiivivormi, siis tunnistab ta deverbaalseteks $u$-tuletisteks küll elu (vrd elama), tegu (vrd tegema) jts, aga käsitab tuletamata juurtüvedena kõiki kolmandavältelisi $u$ - ja $i$-deverbaale, kus sufiks nominatiivis fonoloogiliselt esile ei tule: lend : lennu (vrd lendama), rutt : rutu (vrd ruttama), näit : näidu (vrd näitama), külv : külvi (vrd külvama), lüps : lüpsi (vrd 
lüpsab), ning loeb need alusverbiga konversioonisuhtes olevaks (Vare 2004: 917-922). Tüvevokaali erinevust ei pea ta takistuseks ei tuletiste ega tuletamata tüvede puhul. Sellist tõlgendust on raske aktsepteerida. Tuletusliide on sõnatüve osa ja nagu lihttüvedel, nii ka tuletatud tüvedel, s.t sufiksitel, on häälikulisi variante ehk allomorfe. Kui selliste allomorfide olemasolu tunnistatakse konsonante sisaldavate liidete puhul (liik-le-ma : liig-el-da, rõóm-us : rõom-sa, lend-ur : lend-uri), siis on loogiline tunnistada neid ka vokaalliidete puhul. Deverbaaliliide $-u$ on fonoloogiliselt muutumatu astmevahelduseta alustüvede korral (elu, tänu), astmevahelduslikes sõnades vahelduvad liitekujud $u$ :o (teg- $u$ : te-o, lug- $u$ : lo-o) või $\varnothing: u$ (lend : lennu, jooks : jooksu), aga ta on ikka üks ja sama sufiks nagu eespool näiteks toodud le-, us- ja ur-liite teisendidki. Nii on seda käsitletud senistes eesti derivatsioonikirjeldustes (Kasik 1975, 2010; Viitso 2003) ja nii argumenteerib seda ka Henn Saari (küll Silvi Varele viitamata) oma põhjalikus konversioonianalüüsis:

„Tüvevokaali ja analoogselt -konsonandi mõiste on lihtne, aga kui ununeb mõistete üksikasjalik eristamine, võib tulla eriti vokaalide kohta paikapidamatuid avaldusi. Nii puudub mõte väitel, et vormides nagu laulust, ropsuga, söödul on $u$ enne lõpukadu olnud sufiks, nüüd aga muutunud tüvevokaaliks. [---] Nagu nüüdissõnades tegu, vedu, nii ka selles tüves [s.t vanas laulu-tüves $-R . K$.] teine $-u$ on 1 ) deverbaalisufiks, 2) selle sufiksi ning seega kogu deverbaali muutetüvevokaal ja 3) edasimoodustuse tüve vokaal.... Nüüdissõnas laul : laulu (om.) : laulu (os.) on teine $u$ endiselt nii see kui ka teine tüvevokaal, ja kui end mitte hirmutada lasta ainsuse nimetavas ega üheski muus vormis toimunud muutusest $u>\varnothing$, siis on ta endiselt ka sufiks" (Saari 1993: 91).

Vare möönab, et tema konversioonikäsituse puhul on „sünkrooniline pilt vokaalivahelduste osas üsna kirju”, ja lisab: „Eelnevat arvestades on siinses käsitluses peetud konversiooni kriteeriumina eesti keeles piisavaks seda, kui substantiivi algvormi tüvi on alusverbi tüvega identne vähemalt selle ühes variandis" (Vare 2004: 921). Aga ka sellest tingimusest ei ole kinni peetud. Identse tüvevariandi võib leida vaid kahetüvelistest sisekaolistest verbidest (jooksma, laulma), vokaaltüvelistel verbidel ei ole aga $u$-liiteliste deverbaalidega üheski vormis identset tüvevarianti (vrd rända-ma: ränna-ta, aga ränd: rännu : rändu; sulge-ma : sule-b, aga sulg : sulu : sulgu). Vare argument on, et „alussõna tüve häälikulisi varieerumisi teises sõnaliigis kohustuslikuks pidada tähendaks konversiooni tõlgitsemisel muutemorfoloogiakeskset lähenemist" (Vare 2004: 921). Tõlgendan tüvemuutuste mittearvestamist vastupidiselt. Algvorm on muutemorfoloogia mõiste. Morfeem (ka tüvimorfeem) on aga EKG sõnastuses „abstraktsioon, mis võib tegelikes konkreetsetes sõnavormides mitmeid kujusid saada" (EKG 1995: 119). Just ühe ja vaid ühes sõnavormis esineva tüvekuju samastamine kogu lekseemiga on põhjendamatult muutemorfoloogiakeskne lähenemine sõnamoodustusele.

Eesti keeles tähistavad kade ja kadu, vali, vale ja valu erinevaid mõisteid. Ajalooliste muutuste tõttu on teatud sõnarühmad nominatiivis konsonantlõpulised, sellegipoolest on palk : palgi ja palk : palga; juht : juhu ja juht : juhi eesti keeles erinevad lekseemid. See erinevus vormistub tüvevokaalis ja just tüvevokaali säilimise tõttu peetakse eesti grammatikakirjelduses traditsiooniliselt põhivormiks genitiivi, mitte nominatiivi. Tõsi, käänamistüüpide eristamiseks sobivat kirjeldust otsides on katsetatud ka nominatiivist lähtuvaid süsteeme (Ahrens 1843; viimati EKG 1995), aga sel juhul pole eesmärgiks 
keele süsteemi kirjeldamine, vaid üksnes võimalikult väikese jäägiga rühmitustunnuste otsimine. Kui aktsepteeritakse vokaalliidete $(-e,-i,-u)$ olemasolu eesti keeles, siis sõnamoodustuse kirjeldus, kus tüvevokaalile tähelepanu ei pöörata, nagu võiks see vabalt vahelduda, on minu tõlgenduses puudulik ega kirjelda eesti keele ehitust ja funktsioneerimist adekvaatselt.

Konversiooni alla ei ole põhjust arvata ka $u$-liiteliste automatiiv-refleksiivverbide (hukkuma, aimuma, hoiduma, leiduma, murduma, sulguma, jätkuma, vrd hukkama, aimama, hoidma : hoiab, leidma : leiab, murdma : murrab, sulgema, jätkama) ja $u$-liiteliste deverbaalnoomenite (hukk : huku, aim : aimu, hoid : hoiu, leid : leiu, murd : murru, sulg : sulu,jätk : jätku) häälikulist tüvesarnasust. Tegemist on kahe erineva liitega. Kui me lihttüvede puhul tunnistame homonüümiat (tee, hari, aru), siis ometi ka liidete puhul.

Kuidas mahuvad desubstantiivse konversiooni alla lööve > lööbima (Vare 2005: 51), tarve > tarbima (Vare 2005: 48), jääb mulle arusaamatuks; eesti tuletussüsteemis on siin tegemist regulaarse $e$-liitelise deverbaaliga $b i$-liitelisest verbist (lööbima > lööve, tarbima > tarve, vrd käibima $>$ käive, joobuma $>$ joove, hälbima > hälve). Ka nõeluma, sõeluma, sõlmima, kerima, nokkima jts puhul ei ole tegemist vaba vokaalivaheldusega (Vare 1993: 43-44), vaid frekventatiivse verbiliitega. Ühesugusel viisil moodustatud sõnad moodustavad morfoloogilise tuletustüübi, mis üldiselt kujutab endast ka tähenduse poolest sarnaste tunnustega sõnarühma. Sõnamoodustussüsteemi ei saa analüüsida pelgalt fonoloogiliste tunnuste põhjal, tuletustüübi semantikast lahus.

\section{Nulltuletus või konversioon}

Kui jätta edasise vaatluse alt kõrvale need eespool käsitletud juhud, mida eesti sõnamoodustussüsteemis saab selgelt identifitseerida liitelise sõnatuletusena, jääb siiski järele mingi hulk identse juurtüvega noomeneid ja verbe. Tuletustüüp on avatud ning eeskätt inglise keele, osaliselt ka keelekorralduslike eelistuste mõjul on tüveline sõnamoodustus eesti keeles elujõuline ja viimastel aastakümnetel levimas. Identse tüve all pean silmas tugevaastmelist vokaaltüve kui kõige täielikumat tüvevarianti. Enamikul juhtudest vahelduvad noomenis ja verbis samad tüvevariandid, mõnel juhul on ühes sõnaliigis võinud toimuda astmeüldistus (luba:loa : luba, aga lubama: lubada:lubab) ja kolmandavältelise noomeni nominatiivist on tüvevokaal enamasti kadunud (uskuma : usub, aga usk : usu : usku).

Kuidas selliseid lekseemipaare eesti tuletussüsteemis kirjeldada? Kui siin on tegemist konversiooniga leksikaalses mõttes (vrd Lieber 2005), siis ei ole nende vahel võimalik osutada motiveeritud tuletussuunda ega derivatsiooniga võrreldavat regulaarset tähendusvahekorda. Kui tegemist on konversiooni kui null-liitelise (vrd Marchand 1969) või liiteta sõnatuletusega (vrd Beard 1995), peab olema võimalik määrata, mis millest on tuletatud. Et tuletussuunda - mis on alussõna, mis tuletis - ei saa määrata struktuuri komplekssuse järgi, tuleb toetuda sisulisele motiveeritusele. Tuletise tähendus põhineb tavaliselt alussõna tähendusel: alussõna leksikaalne tähendus ja tuletusliite kategoriaalne tähendus kujundavad üheskoos tuletise derivatiivse tähenduse. Et noomenist sufiksita moodustatud verbi või verbist sufiksita moodustatud noomenit võiks pidada tuletiseks, peab ka selle derivatiivne tähendus ole- 
ma võrreldav sufiksiliste tuletiste derivatiivsete tähendustega. Tuletisele peab liite puudumisest hoolimata lisanduma selline kategoriaalne tähendus, mis teistes tuletustüüpides lisandub tuletusliitega.

Eesti keeles on nende, teoreetiliste diskussioonide tulemusel esitatud kriteeriumide järgi noomeni ja verbi konversiooni puhul selgelt tegemist nulltuletusega. ${ }^{2}$ Identse tüvega noomeni ja verbi tuletussuhe võib olla selline, et noomenist on tuletatud verb (a) või verbist on tuletatud noomen (b):

(a) puur : puuri > puurima, liim : liimi > liimima, saag : saagi $>$ saagima, kõblas : kõpla > kõplama, hari : harja > harjama, vänt $:$ vänta > väntama, julge > julgema, kuiv : kuiva > kuivama.

(b) mõjuma $>$ mõju, kuluma $>$ kulu, uskuma : usub $>$ usk : usu, sundima : sunnib > sund : sunni, kõndima $:$ kõnnib $>$ kõnd $:$ kõnni, röövima $>$ rööv $:$ röövi, jahtima : jahib > jaht : jahi.

Tuletussuund põhineb tähendusanaloogial samasugust derivatiivset suhet esindava sufiksilise sõnatuletusega. Nulltuletuse puhul on oluline, et alussõna ja tuletis moodustavad sõnapaari, millel on liitelise sõnatuletuse valdkonnas sellega kõrvutatavaid samasuguses tähendusvahekorras olevaid lekseemipaare.

Järgneva rühmitamise aluseks on eesti sõnatuletussüsteemis väljendatavad derivatiivsed tähendused, nagu need liitelise sõnatuletuse osas on esitatud raamatus „Eesti keele sõnatuletus” (Kasik 2010). ${ }^{3}$

A. Suurima rühma nulltuletistest moodustavad denominaalsed verbid. 4 Derivatiivse tähenduse järgi jagunevad sellised verbid kolme rühma.

1. Tuletussuhe alussõna ja tuletatud verbi vahel on instrumenta ti ivn e. Alussõna märgib kõige üldisemas mõttes vahendit, millega midagi tehakse või varustatakse või (ainesõnade puhul) kaetakse. Liitelises tuletuses moodustatakse selles tähenduses verbe ta-liitega (hööveldama, pidurdama, ólitama, trellitama), sta-liitega (relvastama, hoonestama), harvem tse(õngitsema, rehitsema, silmitsema) või le-liitega (vihtlema, kätlema).

Sellesse rühma kuulub valdav osa denominaalsetest nulltuletistest: näiteks puur > puurima, liim > liimima, nii ka saagima, kõplama, pallima, käiama, nõelama, korkima, haakima, kammima, kraapima, süstima, ohjama, sarjama, ketrama, rulama, kruvima, hanguma, raalima, kurnama, pumpama, linguma, vinnama, väntama, kaaluma, sahkama, rooskama, tallama, ambuma, nõelama, kütkema, sõnama, telkima; raamima, lappima, plommima, plaatima, pärgama, paikama, soolama; kuldama, krohvima, tahmama, kittima, spoonima, värvima, tõrvama, pihkama, lupjama, salvima, pindama.

Siia rühma paigutub ka neologismipaar lõit > lõitma. Mõned konkreetse tähendusega noomenist tuletatud verbid on leksikaliseerunud tähenduselt abstraktsemaks, aga ka nende taga võib tajuda vahendivahekorda: rist $>$ ristima, palk > palkama, viit > viitama, lävi > lävima, kord > kordama, suund > suunama, silm > silmama, lõug > lõugama, pöör > pöörama.

2 Kas nulltuletust tõlgendada null-liitega või liiteta sõnatuletusena, see on eeskätt teoreetilise fonoloogia probleem ja on tuletussüsteemi funktsionaalse kirjelduse aspektist teisejärguline.

3 Selles raamatus on nulltuletust mõne näitega illustreeritult küll nimetatud (Kasik 2010: 10), aga ei ole lähemalt analüüsitud.

4 Denominaalsete verbidega sama(de)sse tuletustüüpi(desse) kuulub ka adverbidest ja partiklitest moodustunud verbe (läbima, järgima), sest need sarnanevad morfoloogiliste ja semantiliste tuletusmallide poolest denominaalsete verbidega (vrd Kasik 2010: 63-88). 
2. Tuletussuhe alussõna ja tuletatud verbi vahel on e s s e n t s i a a ln e. Tuletis märgib alussõna olemasolu; toimimist või olemist alussõnaga tähistatud rollis või seisundis. Selles tähenduses tuletatakse liidete abil verbe kõige rohkem adjektiividest, aga ka substantiividest ja partiklitest $t a$-liitega (kavaldama, tohterdama, sabatama, redutama), sta-liitega (kurvastama, uhkustama, sõbrustama), tse-liitega (tolatsema, giiditsema, kadetsema), nda-liitega (mustendama, narmendama), le-liitega (laisklema, vaevlema), ne-liitega (eelnema, järgnema, koosnema, võlgnema).

Nulltuletistest kuuluvad sellesse rühma näiteks arst $>$ arstima, kütt $>$ küttima, nii ka orjama, kokkama, nuhkima, juhtima, vahtima; lõhnama, lehkama, maitsema, julgema, kuumama, mustama, laiama; järgima, vajama.

Leksikaliseerunud tähendusega nulltuletistest võib sellesse tähendusrühma lisada hõlmama ja kohtama.

3. Tuletussuhe alussõna ja tuletatud verbi vahel on resultatiivne. Alussõna märgib kõige üldisemas mõttes tulemust, mis tekib või mis saadakse või eraldatakse verbiga tähistatava protsessi tagajärjel. Sõltuvalt sellest, kas tegemist on transitiivse või intransitiivse verbiga, võib muutus olla kausatiivne (keegi/miski põhjustab muutuse) või automatiivne (muutus toimub). Muutusverbe tuletatakse põhiliselt adjektiividest, aga mõnel määral ka substantiividest ja adverbidest. Kausatiivseid muutusverbe tuletatakse $t a$-liitega (madaldama, silbitama, püstitama, taastama), sta-liitega (peenestama, pruunistama, aurustama) ja $i$-liitega (joonima, sõlmima, kerima). Intransitiivseid muutusverbe tuletatakse ne-liitega (halvenema, vananema, kivinema, mõranema, paljunema, taganema) ja u-liitega (külmuma, niiskuma, punguma, puituma, kalduma, mööduma).

Nulltuletistest kuuluvad denominaalsete kausatiivide rühma näiteks rohi > rohima, haav > haavama, nii ka avama, muldama, koguma, ruunama, vôlvima, trahvima, hindama, kuhjama, koormama, sodima, saastama, sulama, piinama, vaevama, hurmama, lummama, varuma, nullima, servama, kordama, kirjama, müürima; omama, nürima, nudima, märgama; läbima, kaasama.

Intransitiivseid muutusverbe on näiteks kuiv > kuivama, orb > orbuma, nii ka nukkuma, raugema, hulluma, külmama, küpsema, kõduma, hirmuma, raevuma, kühmuma, kortsuma.

Kaudsemalt on selle tähendusrühmaga seotud leksikaliseerunud tuletised narrima ja tõdema.

B. Teine nulltuletiste moodustussuund lähtub verbist. Suurema osa sellest rühmast moodustavad tuhmunud ja läbipaistvuse kaotanud ajaloolised $u$ - ja $i$-tuletised, aga on ka mõningaid juurtüvesid. Et tuletuse aluseks on verb, siis on verbaalsus säilinud ka tuletises. See tähendab, et tuletises sisaldub verbi tähendus, millele võib, aga ei pruugi lisanduda muid semantilisi tunnuseid. Tuletus võib muuta ka ainult sõnaliiki, alusverbi semantikat muutmata. Protsessitähenduse säilimine noomenis on põhikriteeriumiks tuletussuuna määramisel, s.t nulltuletise deverbaaliks liigitamisel. Verbist tuletusliidete abil tuletatud noomenid nimetavad protsessi (lugemine, opetus, teke, arutelu, mü̈̈k, häving) või üldistatult protsessi argumente: tegijat (ootaja, lendur, jooksik), tegevuse tulemust (luuletus, tuletis, tõlge), vahendit (väetis, sulgur, koputi) või objekti (teade, söök, andam).

Tegijat ja tegevusobjekti tähistavad tuletised, ka osa tegevusvahendit märkivatest tuletistest, on tähenduselt konkreetsed ja vastanduvad protsessi- 
tähendusele, teine osa tuletistest (enamasti protsessi tulemusele või vahendile viitavad) on derivatiivses mõttes polüseemilised ja nende tähendus võib kontekstuaalselt varieeruda, s.t nad võivad tähistada nii protsessi kui ka selle tulemust või vahendit: ehitus võib tähistada nii ehitamist kui ka valmis hoonet, kirjeldus nii kirjeldamist kui ka protsessi tulemusena valminud teksti, toetus võib märkida nii toetamist kui ka vahendit, millega kedagi või midagi toetatakse, küte niihästi kütmist kui ka küttematerjali. Ka protsessi tähistavad deverbaalid võib tähenduse järgi liigitada kahte allrühma: mine-tuletised on ajatunnuse suhtes neutraalsed, nad väljendavad kestvat protsessi, teiste liidetega tuletatud nn lühideverbaalid võivad sisaldada ajalise piiratuse tunnust, vrd muutumine ja muutus, torkamine ja torge, tegemine ja tegu. Kirjeldatud omadused on iseloomulikud ka liiteta tuletatud deverbaalidele.

Deverbaalne nulltuletis väljendab enamasti protsessi ja on sel juhul tähenduselt lähedane mine-tuletisega: levima $>$ levi, kõndima $>$ kõnd, nii ka ravi, mõrv, streik, reis, matk, lein, sund, sünd, seks, samm, usk, turv, neim.

Ajaliselt määratletud, nn tegevuse üksikjuhtu märkivad on neist selgemalt mõrv, streik, matk, reis, samm.

Protsessi nimetavate lekseemide rühma kuulub ka deskriptiivsetest tüvedest iseseisvateks noomeniteks leksikaliseerunud sõnatüvesid: mühama > müha, kohama > koha, lorama > lora, vohama > voha, kõlama > kõla, lõoskama > lõ̃sk.

Nii protsessi kui ka selle tagajärge väljendavatena on võimalik tõlgendada näiteks deverbaale tulv, mõõn, pais, kulu. ${ }^{5}$

Autode tulv Pärnusse algas juba laupäeval.

Tulvad ujutasid üle 15 rannaküla ja kümneid mereäärseid laagriplatse.

Tormab öises kõrbes, lihased jõutundest paisul.

Ajalugu paistab nagu pais kärestikusel jõel.

See ongi kirjaoskuse mõõna peamine põhjus.

Mõõna ajal on mõlemad läbipääsud päris kuivad.

Määravaks osutus energia ja materjali kulu.

Ettevõtte kulud võib tuludest maha arvata.

$L u b a$ on tõlgendatav nii protsessi, selle tulemuse kui ka vahendina:

Tema lahkel loal olen seal korduvalt käinud.

Kui tööle võetakse alaealine, on vajalik lapsevanema luba.

Et trahvisumma on kõrge, siis on mul mõlemal korral load ära võetud, olen sõitnud ajutise juhiloaga.

Nulltuletuse keskseid probleeme on tuletussuuna tuvastamine. Regulaarse tuletuse puhul vastab tuletise leksikaalne tähendus selle derivatiivsele tähendusele, s.t on kogu tuletustüübis ühesugune. Aga üksiktuletised võivad leksikaliseeruda konkreetses tähenduses või nende tähendus võib varieeruda sõltuvalt kontekstist. Liitega tuletiste analüüsil ei ole ka leksikaliseerunud tuletiste puhul enamasti probleeme tuletussuuna tuvastamisega, sest tuletis on struktuurilt komplekssem kui alussõna, sisaldades alussõna tüve ja liite. Nulltuletuse puhul põhineb tuletussuuna tõlgendus aga üksnes kahe samatüvelise sõna semantilisel vahekorral ja tähendusnihked võivad semantilisi

${ }^{5}$ Lausenäited on pärit Keeleveebist: Keeleveeb > Korpused > Tasakaalustatud korpus. 
suhteid muuta. Näiteks deskriptiivne tüvi viba on substantiivina leksikaliseerunud tähenduses 'õngeritv' ja kaotanud algse protsessitähenduse, mistõttu vibama ja viba vahel ei ole teiste deskriptiivtüvedega võrreldavat deverbaalset tähendussuhet (vrd kohama $>$ koha, lorama $>$ lora). Tänapäeva keele seisukohast on tähendussuhe pigem instrumentatiivne ja tuletussuund viba $>$ vibama $(\operatorname{vrd}$ puur $>$ puurima, saag > saagima $)$.

\section{Laensõnad}

Suur ja üha kasvav rühm samatüvelisi noomeneid ja verbe on päritolult laensõnad. Laensõnad on üldiselt muganenud eesti keele fonoloogilise ja sõnastruktuuriga. Laensõna vanus peegeldub mingil määral sõnakujus: mida vanem laensõna, seda muganenum. Osa mitmesilbilistest laensõnadest on kohanenud keeles varem olnud liiteliste sõnastruktuuridega ja meenutavad oma fonoloogilise kuju poolest tuletisi. Erinevus on selles, et laensõnal pole harilikult lekseemina käibivat alussõna. Eesti verbituletiste struktuuritüüpidega kohanenud laensõnakujud on näiteks:

-(1)da: kritseldama, tükeldama, tärgeldama, heegeldama, guugeldama

-tse: manitsema, kammitsema, hillitsema, kiratsema, märatsema, ravitsema, tarvitsema, tõlgitsema, valitsema

-le: kemplema, vaidlema, piidlema

Kui verbiga paralleelselt on laenunud ka samatüveline noomen, on verbitüvele lisandunud eesti verbiliide (vrd tükk ja tükeldama, juubel ja juubeldama, vang ja vangitsema, riid ja riidlema).

Eesti keele sõnastruktuuri reeglitega kohanemata võõrverbid on eeri-lõpulise tüvega: aktiveerima, isoleerima, improviseerima, instrueerima, raporteerima, kritiseerima, organiseerima, projekteerima, retsenseerima. Kui eesti keelde on laenunud ka samatüveline noomen, soovitavad keelekorraldajad eeri-liiteliste verbide asemel kasutada lühemat ja kompaktsemat nulltuletist (vt nt Erelt 2007: 255-256). Et selline sõnakasutus eriti ühesilbilise või rõhulise lõppsilbiga laentüvede korral vastab sõnastruktuuri poolest eesti keeles käibel olevale tuletustüübile, lisandub noomenitüvelisi liiteta verbe ka spontaanselt, ilma soovituseta: normima, remontima, plaanima, analüüsima, protestima, boikottima, tapeetima, emailima, kloorima, kontrollima, galoppima (vt lisanäiteid Vare 2005: 56-57). Seda protsessi ei ole põhjust pidada sõnamoodustuseks: neid verbe ei tuletata noomenitest teatud tähenduste väljendamiseks, vaid kohandatakse olemasolevad keerulise struktuuriga laenverbid eesti keele sõnastruktuuriga.

Teine kiiresti kasvav laensõnade rühm on ühesilbilised inglise laensõnad, mis lähtekeeles on kasutusel nii noomenina kui verbina: meik ja meikima, rokk ja rokkima, klikk ja klikkima, bluff ja bluffima, reiv ja reivima, meil ja meilima, fänn ja fännima, tšekk ja tšekkima, haip ja haipima, jämm ja jämmima, folk ja folkima, vokk ja vokkima, kaif ja kaifima, spämm ja spämmima, diil ja diilima, drink ja drinkima, link ja linkima, zuum ja zuumima, test ja testima, skaip ja skaipima, skoor ja skoorima. Lähtekeeles kahesilbilise tüvega on ralli ja rallima. Tüvevokaal ja sellega automaatselt seostuv astme- 
vahelduslik muutmistüüp kujutavad endast laensõnade kohanemist eesti keele morfoloogilise süsteemiga: aluseks on ühesilbilised inglise tüved: shop, fan, surf, click jts, kus mingit vokaali ei ole. Osa neist verbidest on laenunud eesti keelde arvatavasti soome keele kaudu, millele viitab $i$-tüvelise verbiga paralleelselt kasutusel olev a-tüveline verb: surfama, klikkama, fännama, meilama, tšekkama, strippama (vt Kasik 2000). Esmavältelise tüvestruktuuriga on kohanenud blogi ja blogima. Selliseid laensõnapaare on eesti keeles ka varasemast ajast, saadud peamiselt saksa, aga ka inglise keele vahendusel: arst ja arstima, maal ja maalima, siht ja sihtima, kraam ja kraamima, kraad ja kraadima, trükk ja trükkima, sport ja sportima, film ja filmima.

Kui on laenatud ainult üks tuletuspaari liikmetest ja teine on eesti keeles iseseisvalt moodustatud, siis vastab tuletus ka semantiliselt eesti keele tuletustüübile (arst $>$ arstima, maalima $>$ maal). Paralleellaenude puhul aga ei ole tegemist eesti keele sõnatuletusega: nii noomen kui ka verb (k.a lihttüveks kohandatud eeri-lõpulised verbid) on laenatud lähtekeeles kasutusel olevas tähenduses ja enamasti on raske, kui mitte võimatu otsustada, kumma sõnaliigi tähendus on primaarne. Kui tähendusvahekord ka vastab eesti keele nulltuletuse semantilistele mallidele, siis on see üksnes juhuslik (vrd saast > saastama ja spämm > spämmima; ori > orjama ja fänn > fännima, värv > värvima ja tapeet $>$ tapeetima). Rochelle Lieber (2004) on analüüsinud konversioonisuhteid uuemas inglise keele leksikas ja tõdenud inglise neologismide baasil, et tähendusvahekorrad ei piirdu afiksilise tuletuse võimalustega. Selliste laenudega tuleb eesti keelde noomeni ja verbi konversioon, mis ei ole enam tuletus ja mis on kõnekeeles levimas juba ka eesti oma sõnavarasse: äri ja ärima (vrd äritsema), moos ja moosima, kott ja kottima, Prangli ja pranglima (viimase näite kohta vt Vare 2005: 40).

\section{Kokkuvõte}

Nulltuletus on liitelise tuletuse kõrval üks eesti keele sõnamoodustusviise. Nulltuletus on suunaga protsess, mille puhul on eristatavad alussõna ja tuletis ning tuletis on semantiliselt alussõnast motiveeritud. Ka alussõna ja tuletise semantiliste vahekordade poolest on nulltuletus paralleelne liitelise sõnatuletusega: nulltuletus väljendab samu derivatiivseid tähendusi kui liiteline tuletus. Nulltuletus on mõnel määral produktiivne noomenitest verbide moodustamisel, deverbaalne noomenituletus on marginaalne, enamiku nulltuletistena tõlgendatavatest deverbaalsetest noomenitest moodustavad ajalooliste muutuste tõttu läbipaistvuse kaotanud ja ühemorfeemiliseks sõnaks muutunud tuletised või deskriptiivtüved.

Inglise laenude mõjul on eesti nulltuletuse süsteem muutumas. Paralleelselt laenatud noomeni- ja verbitüved on kasutusele võetud lähtekeelest laenatud tähenduses ja kujul, ilma et laenatud verbitüvesid enam kohandataks eesti keele liitelise verbituletussüsteemiga. Seda suunda soosib ka keelekorraldus. Neologismidena laenatud noomeni- ja verbitüvede vahel ei ole eesti tuletussüsteemile omaseid süsteemseid tähendussuhteid ja nulltuletuse kõrval levib eesti keele sõnavarasuhetes indoeuroopa keelesüsteemi iseloomustav leksikaalne konversioon. See on juba hakanud mõjutama ka eesti algupärast sõnaloomet. 


\section{Kirjandus}

A h r e n s, Eduard 1843. Grammatik der Ehstnischen Sprache Revalschen Dialektes. Reval.

B e a r d, Robert 1995. Lexeme-Morpheme Base Morphology. Albany: SUNY Press.

$\mathrm{C}$ l a r k, Eve, C l a r k, Herbert 1979. When nouns surface as verbs. - Language, kd 55, nr 4, lk 767-811.

D o n, Jan 1993. Morphological conversion. OTS Dissertation Series. University of Utrecht.

EKG = Mati Erelt, Reet Kasik, Helle Metslang, Henno Rajandi, Kristiina Ross, Henn Saari, Kaja Tael, Silvi Vare, Eesti keele grammatika I. Morfoloogia. Sõnamoodustus. Peatoim M. Erelt. Tallinn: Eesti Teaduste Akadeemia Eesti Keele Instituut, 1995.

E r e lt, Tiiu 2007. Terminiõpetus. Tartu: Tartu Ülikooli Kirjastus.

Ka s i k, Reet 1975. Verbide ja verbaalsubstantiivide tuletusvahekorrad tänapäeva eesti keeles. - Keele modelleerimise probleeme 5 (Tartu Riikliku Ülikooli toimetised 363.) Tartu, lk 3-162.

K a s i k, Reet 2000. Kas surfima või surfama? - Keel ja Kirjandus, nr 12, lk 889890.

K a s i k, Reet 2010. Eesti keele sõnatuletus. Kolmas, parandatud trükk. Tartu: Tartu Ülikooli Kirjastus.

K a s i k, Reet 2011. Sõnatuletus leksika ja grammatika vahel: $n d$ - ja $n d u s$-liitelised verbaalnoomenid. - Emakeele Seltsi aastaraamat 56. Tallinn: Emakeele Selts, lk 63-90.

K e r g e, Krista 1990. Liitsõna. Mõisteid ja seoseid. Soome-Eesti kontrastiivseminar (Tallinn 1988). Eesti NSV Teaduste Akadeemia ühiskonnateaduste osakond. Preprint KKI-51. Tallinn.

Li e be r, Rochelle 2004. Morphology and Lexical Semantics. Cambridge: Cambridge University Press.

L i e b e r, Rochelle 2005. English Word-Formation Processes. - P. Štekauer, R. Lieber (toim), Handbook of Word-Formation. Dordrecht: Springer, lk 375-427.

M a r chand, Hans 1969. The Categories and Types of Present-Day English Word-formation. Munich: Beck.

$\mathrm{P}$ e $\mathrm{n} \mathrm{n}$ a n e n, Esko 1971. Conversion and zero-derivation in English. (Acta Universitatis Tamperensis 40.) Tampere: Tampereen Yliopisto.

Pl a g, Ingo 1999. Morphological Productivity: Structural Constraints in English Derivation. Berlin: Mouton de Gruyter.

$\mathrm{R}$ ät s e p, Huno 2002. $i$-sufiksilistest verbidest eesti keeles. - H. Rätsep, Sõnaloo raamat. Tartu: Ilmamaa, lk 143-159.

S a a r i, Henn 1993. Sõnamoodustuse mõisteid. Liigivaheldus. - Keel ja Kirjandus, nr 2, lk 87-97; nr 3, lk 148-159; nr 11, lk 649-659; nr 12, lk 726-736.

Š t e k a u e r, Pavol 1996. A Theory of Conversion in English. Frankfurt am Main: Peter Lang.

Š t e k a u e r, Pavol 2006. On the meaning predictability of novel context-free converted naming units. - Linguistics, $\mathrm{kd} \mathrm{44,} \mathrm{nr} \mathrm{3,} \mathrm{lk} \mathrm{489-539.}$

Š t e k a u e r, Pavol, Va l e r a, Salvador, K ör t v e l y e s s y, Livia 2012. Word-Formation in the World Languages. A Typological Survey. Cambridge: Cambridge University Press.

Va r e, Silvi 1993. Konversioonist eesti keele sõnamoodustuses. - Virittäjä, nr 1, lk 34-50. 
Va r e, Silvi 2004. Põgusalt ühest leksika ja süntaksi piirinähtusest. - Keel ja Kirjandus, nr 12, lk 915-922.

Vare, Silvi 2005. Eesti keele verbimoodustus: desubstantiivne konversioon. Emakeele Seltsi aastaraamat 50. Tallinn: Emakeele Selts, lk 39-65.

Vi it s o, Tiit-Rein 2003. Structure of Estonian language. Phonology, morphology and word-formation. - Estonian Language. Toim M. Erelt. (Linguistica Uralica Supplementary Series 1.) Tallinn: Estonian Academy Publishers, lk 9-129.

\section{Zero-Derivation and Conversion in Estonian}

Keywords: word-formation, conversion, zero-derivation, Estonian language, language contact

The article discusses noun and verb conversion in Estonian. Unlike in analytical languages, such as English, Estonian conversion is not about homonyms, as in Estonian nouns and verbs take different inflectional paradigms. In addition, Estonian word stems may have different phonological shapes, neither need the stem allomorphs of a stem-sharing noun and verb be similar. The existence of mono-vowel derivative suffixes $(-u,-i,-e)$ poses an additional problem of how to differentiate between a vowel suffix and a stem vowel.

The first part of the article explains the boundaries of suffixal derivation and conversion in stem-sharing nouns and verbs. The second part analyses the semantic relations of stem-sharing nouns and verbs, pointing out that from the semantic point of view the conversion of Estonian nouns and verbs is zero-derivation. This is an oriented process, where the base word and the derivative can be distinguished, while the latter is semantically motivated by the former. In view of the semantic relations of the base word and the derivative, zero-derivation is also parallel with suffixal derivation as they both express the same categorical meanings.

Due to the English loanwords that have recently entered Estonian in considerable numbers the Estonian system of zero-derivation has begun to change. The noun and verb stems borrowed in parallel have been adopted into use directly in the borrowed meaning and shape, without adapting the borrowed verb stems to the Estonian system of suffixal derivation. The noun and verb stems borrowed as neologisms lack the systemic semantic relations inherent in Estonian derivation. Thus, in parallel with zero-derivation, Estonian has begun to use lexical conversion, which is typical of the Indo-European language system. This is already showing in original Estonian word-making.

Reet Kasik (b. 1946), PhD, senior researcher, University of Tartu, Institute of Estonian and General Linguistics, reet.kasik@ut.ee 